DOI: $10.17516 / 1997-1370-0572$

УДК 902(517)

\title{
A "Forgotten" Coin-Shaped Indication from the Early Medieval Burial Complex in Tuekta (Central Altai)
}

\author{
Nikolay N. Seregin*a, Vladimir V. Tishin ${ }^{b}$ \\ and Vadim V. Serov ${ }^{c}$ \\ altai State University \\ Barnaul, Russian Federation \\ ${ }^{b}$ Institute for Mongolian, Buddhist \\ and Tibetan Studies of the Siberian Branch of the RAS \\ Ulan-Ude, Russian Federation \\ ${ }^{c}$ Altai Institute of Economics \\ Barnaul, Russian Federation
}

Received 10.10.2019, received in revised form 18.03.2020, accepted 28.05.2020

\begin{abstract}
The article is dedicated to the publication of a unique find that is a coin-shaped indication from the early medieval burial complex in Tuekta (Central Altai) and an attempt of its comprehensive analysis. Excavations of the archaeological site were carried out in the 1930s during the work of the Sayan-Altai expedition led by S.V. Kiselev, however, since then, the metioned find has not attracted the attention of researchers. The article presents a detailed description of the coin-shaped indication and the analysis of the applied images, it is there also given the characteristic of the archaeological context of the discovery of the object and discuss the possibility of reading fixed signs. As a result, it is presented an attempt to interpret the product in a specific historical and cultural context taking into account the materials received over the past decades. It should be noted the absence of identical archaeological finds in the numismatic collections. At the same time, an analysis of the details of the image on the coin-shaped indication made it possible to outline a wide range of analogies demonstrating the complex processes of cultural contacts in large territories of Eurasia over a long chronological period. The authors came to the conclusion that the analysed product, as well as other like finds from the archaeological sites of the Türks of Inner Asia, to be a kind of "social markers", demonstrating their owners' belonging to the elite strata of the nomadic society and, possibly, reflect their specific authority. The proposed interpretation of such things, given their scarcity, as well as the context of discovery not being obvious, seems debatable and, of course, requires the emergence of new data as a result of further archaeological research.
\end{abstract}

\footnotetext{
(C) Siberian Federal University. All rights reserved

* Corresponding author E-mail address: nikolay-seregin@mail.ru ORCID: 0000-0002-8051-7127 (Seregin); 0000-0001-7344-0996 (Tishin)
} 
Keywords: Altai, Early Middle Ages, coin-shaped indication, Tuekta, Early Turks, burial monud, interpretation, social history.

The research was funded by RFBR according to the project №18-09-00536a “Chronology of Altai archaeological complexes of the Xiongnu-Xianbei time and the early Middle Ages (II century BC - XI century AD)", as well as in the framework of the Comprehensive Program of Basic Research of the SB RAS XII. 191.1.2. Intercultural interaction, ethnic and socio-political processes in Central Asia, AAAA-A17-117021310264-4.

Research area: archeology.

Citation: Seregin, N.N., Tishin, V.V., Serov, V.V. (2020). "Forgotten" coin-shaped indication from the early medieval burial complex in Tuekta (Central Altai). J. Sib. Fed. Univ. Humanit. Soc. Sci., 14(1), 85-97. DOI: 10.17516/1997-1370-0572.

\section{Introduction}

Today, as a result of archaeological works has carried out in various parts of Inner Asia by many generations of researchers, it has been accumulated a huge amount of data on the history and culture of early medieval nomads. Unfortunately, a significant part of the materials received has not been published yet or been put into scientific use only partially. Collections of finds that could become an important source for the reconstruction of processes taking place in the region are stored in museums being inaccessible to a wide range of researchers. Meanwhile, the return to such "forgotten" things in the light of new materials sometimes becomes very relevant. it is hardly a dubious fact that a high-quality publication and a detailed interpretation of the materials of past years excavations are currently a separate research area, characterized by its difficulties, but of great importance.

A vivid example of collections of finds from the sites of the early Middle Ages, which, in fact, are still not put into scientific use, are materials obtained as a result of excavations of the Tuekta monument in Central Altai (Fig. 1). The beginning of research at this multi-period site dates back to 1935, when the work was carried out by A.P. Markov and S.M. Sergeev. In 1937, the excavations were continued by the Sayan-Altai expedition led by S.V. Kiselev. In the published data on the results of that work, there are mentions of thirteen investigated mounds of early medieval Türks (Evtiuhova,
Kiselev, 1941: 113-114, Fig. 65-68; Kiselev, 1949; 1951; Gavrilova, 1965: 6). The surviving burial inventory included a series of rare and "prestigious" finds (a belt with gold lining, horse equipment, a silver vessel, remnants of silk clothing, etc.). One of the things to deserve close attention is a gold coin-shaped indication. A black-and-white photograph of the product is presented in summarizing monographs by S.V. Kiselev (Kiselev, 1949, tab. LII. 3; Kiselev, 1951, tab. LII.-3), which have remained basic in the study of various aspects of ancient and medieval archaeology of Southern Siberia for a long time. Moreover, over the following years, this find did not attract the attention of researchers, despite the fact that a whole series of special publications was devoted to the analysis of the inventory of the archaeological monuments of the Türks. It was in 2016, when one of the authors of this article, having the opportunity to access the collections of the State Historical Museum (SHM), thanks to the assistance of Yu.V. Demidenko, a researcher at the Department of Archaeological Monuments, examined the coin-shaped indication in situ and then they were obtained its high-quality photographs.

The goal of this article is to introduce of a rare find from the Tuekta complex for a long time remained out of view of researchers into scientific use, The authors presented an experience of the comprehensive characteristics of a coin-shaped indication and an interpretation of the product in a specific historical and cultural 


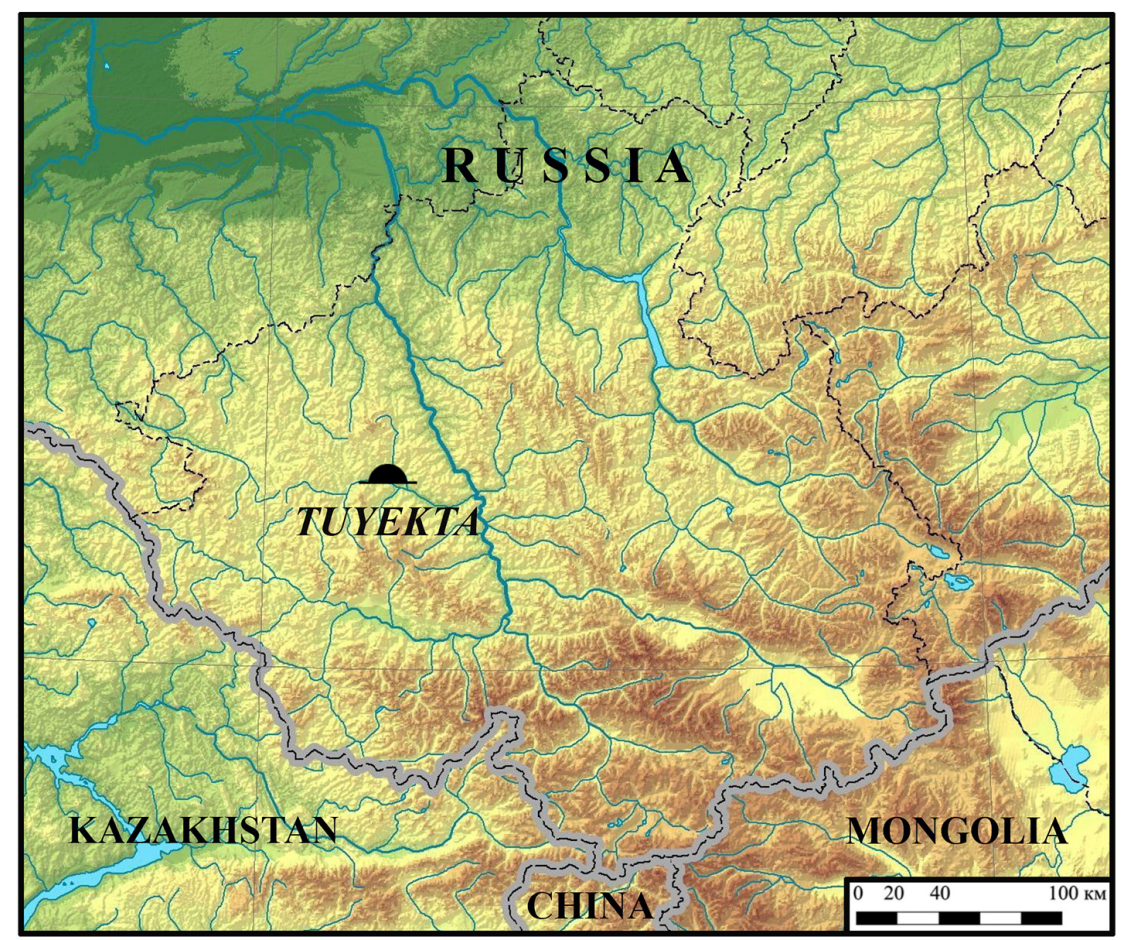

Fig. 1

context, taking into account materials obtained in recent decades.

\section{An Identification of the Object}

The examined thing from the Tuekta burial is a thin circular plate of gold, $2.3 \mathrm{~cm}$ in diameter, with an image stamped on it, as well as two small holes located diametrically opposite along the top and bottom edges of the plate (Fig. 2-4).

Today, it has been attested the discovered in the vast territories of Eurasia a number of similar things to be generally defined as "bracteates" or "indications" (Klyashtornyj, Savinov, Shkoda, 1990; Ochir et al., 2013; Gorbunov, Serov, 2015; Shmonievskij, 2016; etc.). The authors of the article use the term "coin-shaped indication", because of implying the conventionality of the relation of the thing analysed to specific numismatic objects and a weak, but its quite traceable connection with coins and coin imitations.

A coin-shaped indication from the Tuekta complex encloses an image in a rim of frequent short dashed lines oriented from the centre to the edges. The distance from this rim to the edge of the plate is about $1,5 \mathrm{~mm}$. A similar design element was typical of some Byzantine gold and Iranian silver coins of period from the last third of the $6^{\text {th }}$ century and the $7^{\text {th }}$ century $^{1}$. In addition, the image in the centre on the thing analysed, representing a human head portrait turned three quarters to the left, also has a similar resemblance to the iconography of some Sogdian numismatic objects ${ }^{2}$. Finally, the location of the runiform inscription to the right and left of the portrait resembles Greek and Latin legends on Early Byzantine solids. Thus, it is possible due the totality of the mentioned attributes of numismatic characteristic a find from Tuekta can be attributed to coinshaped objects.

\footnotetext{
1 For example, they are on the solids of Constantine IV Pogonatos (Sear, 1987: 233, No. 1157), Justinian II (Ibid: 246, No. 1248; 255, No. 1312), as well as on the late Sassanian drachms.

2 For example, it is the image on the coins of Usrūshana (Smirnova, 1981: 324-326).
} 


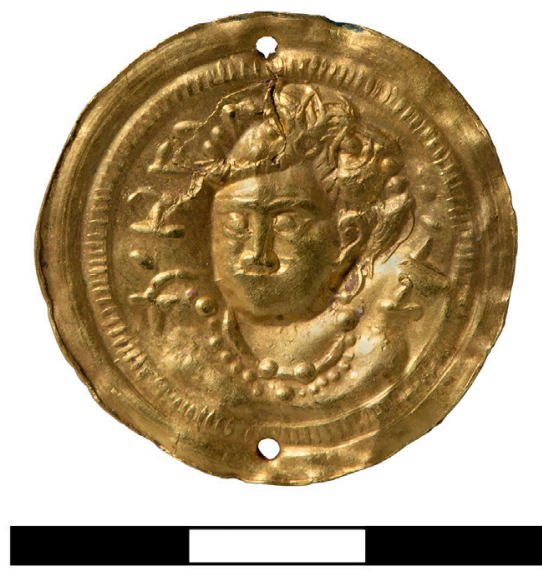

Fig. 2
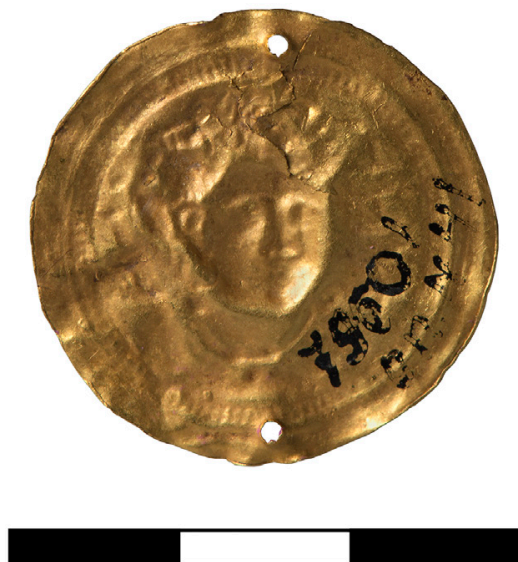

Fig. 3
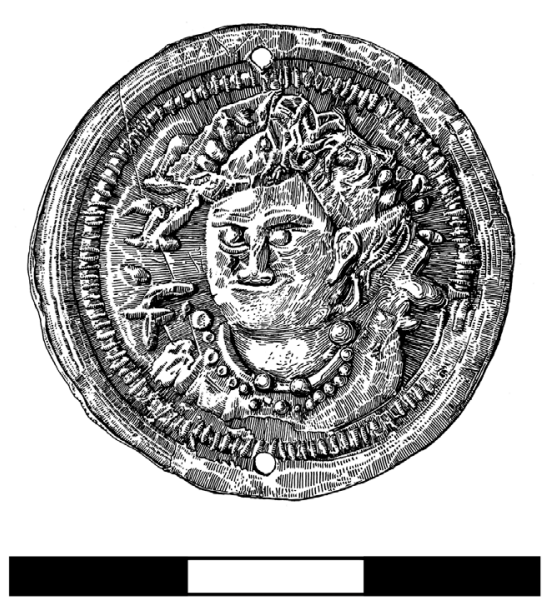

Fig. 4

The anthropomorphic portrait, located in the centre of the coin-shaped indication, has no direct analogies with the currently known examples of artistic creativity of Early Medieval Eurasia. Some cultural traditions can only be guessed in the individual elements of the image, but the clarification of their connections with artistic prototypes should be the subject of a rigorous cultural analysis, which is not included in the list of tasks of this publication. In order to find out who or what is depicted on the examined thing from the Tuekta burial, it is advisable to look at the individual elements making up the portrait. All replicated, especially stamped images, and even more so related to the sacred sphere, inevitably undergo sche- matization. This circumstance, even if we are talking about the fine canon that has not been formed yet, facilitates the search for analogies in the world of art and, accordingly, allows finding prototypes that influenced the creative style of the master who made the Tuekta find.

It seems reasonable to single out several basic elements of a central anthropomorphic image that have the characteristics of identifying features.

Hairstyle. It is clearly not Sogdian, which could be assumed primarily due to the geographical proximity of Altai to Semirech'e and, in particular, to Sogd. Sogdian characters in famous images are presented in headwear or trimmed more simply, even vulgarly. The hair- 
do of the person depicted on the coin-shaped indication is complex; hair is collected in several bunches in the form of very characteristic "nests"; on top of the entire hairstyle, in groups of two or three, there are round and oblong "beads", which, obviously, should have depicted a kind of garland or the top of the pins that held the tufts of hair. An additional decoration of the hairstyle in the foreground is something resembling a large brooch in the form of a flower with a single petal facing up; it is located between the hair strands (however, this peaked petal may well turn out to be a stylized tongue of flame). In addition, there is a brooch-like top that is vaguely reminiscent of a blossoming flower bud on the best-preserved image of one of the hair bunches. The hair in the portrait is depicted in rare deep relief lines arranged in a certain orderliness.

A similar manner of depicting the exquisite hairstyle of people and deities is known in territories influenced by Buddhist cultural tradition. For example, it can be recognized in the image of a bodhisattva from the temple in Turfan, dating back to the $9^{\text {th }}$ century; earlier specimens are found in sculptural compositions from Gandhāra (Pugachenkova, 1982: 142, ill. 147). In the Gandhāra sculpture tradition, one can find a hairstyle element, which is similar to the aforementioned one, in the form of a hair bunch twisted into a large "bump" with a decoration typical for Buddhist art that is a lotus flower over the hair (Pugachenkova, 1982: 91, ill. 95).

The feature noted in the portrait from Tuekta that is the depiction of hair strands with the help of rare but deep and large lines is typical of Kushan art (Pugachenkova, 1971; Drevneishie gosudarstva..., 1985: 112-113), which, as is known, affected the art of not only the political successors of Kushan, but also the territories adjacent to it, for example, Xinjiang ${ }^{3}$.

Thus, the hairstyle design features on a coin-shaped indication demonstrate the connection of the product with distant Bactrian traditions, which were refracted and get a new look in Tokharistan (Mkrtychev, 2002: 16) or

\footnotetext{
3 A vivid example of this is the male head from the Shikshin (Qigexing) Temple, dating from the $6^{\text {th }}-8^{\text {th }}$ centuries. (D’yakonova 1995: 93).
}

East Turkestan. In addition, the it is noticeable the influence of Buddhist art of the first centuries A.D. in the details of the image.

Ear. It is a noticeable element of the portrait, but not very attractive in terms of artistic performance, because both of characterizing by simplicity, close to schematism, and a mismatch of three quarters of the angle chosen by the artist that is why the ear looks as if the portrait to be deployed in profile. There is no characteristic of Buddhist fine art in the form of a pulled down lobe here. It is difficult to guess the presence of an earring, consisting of two beads of different sizes, located one below the other; a thin ring of irregular shape is inserted through the smaller upper one, which is inserted into the ear. Similar earrings from different-sized beads are found on coin portraits of Sogdian rulers, in particular, on the coins of Usrūshana mentioned above, as well as on the coins of Chāch of the $6^{\text {th }}-7^{\text {th }}$ centuries. Their possessions were located far to the north of Tokharistan and northwest of Xinjiang, being therefore, closer to Altai. Possibly, earrings as an important detail of the image show the participation in the interethnic cultural transmission of precisely these regions of Eastern Sogd.

Eyebrows and nose. The lack of professional performance of this element is manifested in the absence of both a hint of following a certain canon (like strongly curved and thin eyebrows and a graceful nose in Buddhist art) and the individuality of the features of the portrait. Due to the schematism that led to the fact that the eyebrows and nose look like a T-shaped bulge that is uniform in height, it is very difficult to determine whether these eyebrows grew together, like in Sogdian portraits, and also what form of nose seen by the master.

Eyes. Being depicted quite roughly, they are not devoid of originality. Following the Buddhist canon is not visible here; moreover, comparison with any well-known art samples is impossible due to the low level of skill of the artist who created the analysed thing. The eyes that are similar in their shape, depict by large stingy lines, are present on portrait images in handicrafts, coins and products of art of various genres and different regions of the Western and Central Asia (D’yakonova, Sorokin, 1960: 
Tables 23-26). The originality of the eyes on the product analysed is in their large size and unusually wide section, even some bulge, which can also be attributed to the inability of the master to accurately convey the features of the image he copied.

Mouth. In the portrait, it is actually absent, due to probably an unintentional external influence, for example, from the robbers. At the same time, it is should be pointed an extraordinary accuracy for this: the convex detail of the image was erased as if by the edge of the eraser, without touching the nose and chin; on the back of the plate, where the "negative" of the portrait is located, the place that corresponds to the mouth of the "positive" is also smooth.

Due to this circumstance, it is impossible to definitely admit the presence of a moustache on the portrait, as well as the presence of the famous Buddha's smile on the lips are the details whose absence or existence would enrich the characteristic of the coin-shaped indication from Tuekta. It can be only assumed that the erased mouth was small, but this detail is characteristic of the fine art of many Asian peoples and periods from the Late Antique polytheistic Greco-Bactria to the Medieval Buddhist Khotan.

Neck jewellery. It consists of two elements, namely a torc with remarkable double beads and a necklace made of pearls or round stones with a large bead in the middle. Portraits with a necklace of this type are found among different peoples of Inner and Central Asia; this detail is also characteristic of Buddhist art (including from Khotan), in connection with which this element of the image cannot act either as a dating sign or as a cultural characteristic. It is a much more remarkable and rare image of a golden "round torc decorated with two circles with a square plate in the middle" that is found only in individual samples of Sogdian painting ${ }^{4}$ and in some portraits of Buddhist de-

\footnotetext{
${ }_{4}$ For example, it was found in the case of the characters of the painting "The Hall of Ambassadors" in Samarqand of the $7^{\text {th }}$ century, who are identified as members of the Chaḡanniān embassy (Albaum, 1975: 39). It should be noted that the indicated "circles" on the torc are not pearls or balls of gold, as in the Tuekta portrait, but disks with "buttons" in the centre, and are separated not with a "square plate", but by a very long
}

ities. The torc, with two large beads connected by a thicker short baffler than the rest of the wire, can be seen exclusively on the coin of the ruler of Chāch. Thus, this is not only a unique subject analogy, but also a direct evidence of a certain cultural borrowing, which was carried out under the influence of some political factor. The torc of the Chāch (or modified Chaḡānīān) type could not appear on the Altai "portrait" by accident. One can only regret that this is the only detail of the image, which largely contributes to clarifying the interpretation of the find in question.

In general, based on the undertaken analysis of the coin-shaped indication from the Tuekta complex, a number of preliminary conclusions can be made. First of all, it is important to emphasize the absence of identical finds among the numismatic collections known to the authors. It seems possible to assert that the coin-shaped indication from the Tuekta complex is the result of complicated and lengthy processes of cultural mutual influence, the beginning of which dates back to the Hellenistic era and the completion took place in the second half of the $1^{\text {st }}$ millennium $\mathrm{AD}$; and geography covers the space from the Northeast Mediterranean to the Northern India and South Kazakhstan.

\section{Archaeological Context of the Find}

The funeral and memorial complex of Tuekta is located near the village of the same name, in the valley of the Ursul river, in the Ongudai district of the Altai Republic (Fig. 1). Judging by the short description presented in the monographs of S.V. Kiselev (Kiselev, 1949: 305; Kiselev, 1951: 542), a gold coinshaped indication was found in the central robbed burial of Mound 2 of the necropolis. In addition, it is mentioned here that during the excavation other things were also recorded, namely gold plaques of various types, two stirrups, an iron shackle on the saddle pom-

jumper (Ibid. Table 14: Western Wall, Detail 1. Man's Head). Approximately the same torc, but with discs that are really separated with a square plate, adorns the neck of a young man pushing birds (Ibid., Table 25. South wall. Young man's head). Ambassadors as representatives of the state could have similar torcs being the official symbols of the sovereign ruler of Chā̄ānīān. 
mel, as well as a bit and cheek-pieces. The coin-shaped indication is described as "a gold plaque with a relief image of the head of the eastern sovereign and with an inscription in letters resembling Orkhon coursive" (Kiselev, 1949: 305; Kiselev, 1951: 542).

The gold coin-shaped indication stored in the Museum Funds, its inventory number is "No. 79601 Op. B 830/41". In the inventory, the thing is described as follows: "The plaque is round, stamped, containing the image of a human head in a diadem, with earrings in the ears and a torc on the neck. There is an inscription around it." 5 The notes indicate that the product was found at the level of the ancient horizon, among the stones of the predatory course. A brief description of other items from the burial of Mound 2 includes the information that traces of silver inlay found during excavations of this object were recorded on two stirrups and a bit.

It should be noted that Mound 2 of the Tuekta burial ground investigated by S.V. Kiselev in 1937, is very unusual for the recorded characteristics of the funeral rite. First of all, according to the author of the excavations, it had the largest embankment in size among the all medieval objects of the site. According to the above information, four stone boxes with an overlap were revealed under the ground structure, three of which, located along the edge, were "accompanying". The central burial was almost completely destroyed by robbers, the fact of which did not allow specifying the features of the realized burial rite. There is information that around Mound 2 the burials under small circular layout, which S.V. Kiselev (Kiselev, 1949: 299-300; Kiselev, 1951: 533-534) also attributed to this complex and interpreted as the graves of the dependent population.

Thus, despite the incompleteness of the available information, which is explained by both the destruction of the complex and the lack of full publication of excavation materials, it is obvious that Mound 2 of the Tuekta necropolis stands out significantly among the wellknown burial sites of the of the Türks in Altai

\footnotetext{
5 According to Yu.V. Demidenko, the text was made in the handwriting of V.P. Levasheva.
}

and adjacent territories. According to the set of characteristics, the central burial of this object can be attributed to a small group of burials of members of the elite of early medieval nomads. It should be noted that two more burials were studied at the Tuekta necropolis (Mounds 3, 4, excavations of 1935) also characterized the material culture of the upper strata of the nomadic society (Evtiuhova, Kiselev, 1941: 113-114). It is significant that another "elite" burial of the Türks was studied at the Balyk-Söök-1 complex located in the immediate vicinity (Kubarev, Kubarev, 2003). It is obvious that a high degree of concentration of early medieval nomads "nobility" burials in this part of the region is not accidental. We should note that all the designated archaeological objects are located next to the chains of "royal" mounds of the Pazyryk culture of the Scytho-Saka Period.

\section{Runic Inscription?}

Despite the fact that the presence of an inscription on a coin-shaped indication from the Tuekta complex was noted by S.V. Kiselev, in subsequent years, it was made no any attempt to read it. The inscription was not attested in any known catalogue. Due to the difficulty to access the find and based on the available photograph, the authors of the article initially made a curious and, as it can be understood now, not serious attempt to read these "letters" identifiying them as signs of the Old Turkic runic writing (Seregin, Tishin, 2017: 259-260).

Upon personal acquaintance with the find, there were discovered the some clarifying details. Firstly, the shape of the signs in the image published by S.V. Kiselev due to its low quality is greatly distorted. After looking the object in situ it became clear that the number of signs was different. This fact makes the earlier reading of the inscription incorrect. Secondly, there are two holes not fixed on the image published. The were made by a sharp object with a circular cross section of $2-2.5 \mathrm{~mm}$ on the radial surface of the indication, located in the upper and lower parts (according to the orientation of the portrait) on the same vertical axis, on the border between the rim and ornamental line. It was not possible to understand how these holes appeared, whether they existed at the time the 
object was discovered, to be then retouched when the photograph was published, or were made later. Since in similar cases of detecting things with holes, the presence of the latter was indicated in the inventory, it is reasonable to incline to the second option.

Based on the mentioned characteristics of the inscription, it seems possible to clarify the shapes of the inscribed signs, admitting their identification as graphemes of the Old Turkic runic writing. Upon closer examination, the signs reveal a resemblance to the Old Turkic runic script typical for monuments of East Turkestan.

Thus, on the left side from the portrait, if looking at it, standing opposite, they can be identified the three signs are read along the edge of the surface of the indication from top to bottom. They are a velarized consonant $/ 1 /$, uvular /q/ and also a sign whose forms can be defined as designation of a hissing sibilant / $/$ /, combined with back vowels (Vasil'ev, 1983: 134 , tab. 25 , st. 14, 21). Two characters can be identified to the right of the image, readable in the same direction, continuing the previous text, but due to a change in angle, from the bottom up. The first of them can be defined as a uvular consonant /q/ (Vasil'ev, 1983: 115, tab. 13), or as a back rounded vowel, that are half-narrow /o/ or narrow /u/ (Vasil'ev, 1983: 98, Table 3). The second can be defined as a back consonant $/ 1 /$.

Transliteration: $1^{1} \mathrm{q} \check{\mathrm{s}}^{1} \mathrm{q}($ or $\mathrm{v}) 1^{1}$

Transcription: (a)lq(i)š q(a)l / (a)lq(i)š ol

Translation: 'a blessing, stay!' / 'blessing that (is)!' or 'it is blessing!'

\section{Commentary:}

The first word alqïs is 'praise, blessing', or in religious texts it is "prayer hymn, prayer, anthem' (Drevnetiurkskii slovar', 1969: 38-39; Sravnitel'no-istoricheskaia, 2006: 600-602). Sir G. Clauson, interpreting the word as 'praise', noted that "originally in the sense of praising God, later also in ordinary human relations, where 'blessing' is sometimes the better translation" (Clauson, 1972: 137).

In the second case, it can be read the verb qal-, which, according to Sir G. Clauson, is "basically 'to remain'; with some idiomatic meanings like 'to be only, to continue to be; to stop, come to a halt; to remain behind, become obsolete" (Clauson, 1972: 615), 'to stay, to remain, to survive', 'to stay in place', etc. (Drevnetiurkskii slovar', 1969: 410).

If one read the first sign of the second word as a rounded vowel, then here it should be seen here the $3^{\text {rd }}$ pers. sing. demonstrative pronoun $o l$, used both in the adjective function as 'that' and in the substantive function as 'he', 'it' etc. (Kononov, 1980: 164).

Both semantically and syntactically, the second variant looks more preferable.

At the same time, it is important to note that it is impossible to identify the considered signs as graphemes of the Old Turkic runic script categorically. Perhaps it should be assumed that these signs were a result of an unskilful (misunderstood?) attempt to copy the legend of some original coin. Such point is based on the possibility of their formalized comparison with signs on gold unilateral imitations of two Byzantine solids of the $5^{\text {th }}-6^{\text {th }}$ centuries from the collection of the British Museum (Stein. IA.XII.b.1; Stein.IA.XII.c.1) (Wang, 2004: 29, fig. 7; The Silk Road, 2004: 144, fig. 37a), imitations of the golden solid of the Byzantine emperor Leon I from Huangzhou 黄州 (Lin Ying, 2005: 17, fig. 5) or a golden one-sided imitation of the Byzantine solid from the tomb of Shi Suoyan 史索岩 (died in 658, buried in 664), near Guyuan 固原 (Lin Ying, 2005: 18, fig. 6) . $^{6}$

\section{Problems of Interpretation of Numismatic Finds from Early Medieval Archaeological Complexes of Inner Asia of the}

Despite the rareness of the finds similar to a coin-shaped indication from the Tuekta complex, the available materials does it possible to discuss the place of such things in the material and spiritual culture of the early medieval Türks of the Inner Asian region.

First of all, one should draw attention to the fact that gold coin-shaped indications were important markers of a social status in the society of nomads of Inner Asia in the $2^{\text {nd }}$ half of the $1^{\text {st }}$ millennium A.D. All the few things

\footnotetext{
${ }^{6}$ We must express our thanks to V.G. Koshevar (Bishkek, Kyrgyz Republic) for his pointing out these examples.
} 
are found in the burials of the "elite" of various levels, differing in specific characteristics of the rite. According to the available data, such things from the complex of Uvgunt (Navan, Sum'yabaatar, 1987; Klyashtornyj, Savinov, Shkoda, 1990) and Shoroon Bumbagar (Ochir et al., 2013: 183-196) illustrate the contacts of the Türks with the Sogdians, reflecting the features of the relationship between the nomadic elite and representatives of the settled agricultural communities at different periods of history. According to proposed readings of runic inscriptions on bracteates in the Tuekta and Uvgunt burials - what is remarkable, is presented here in single exemplars, - both contexts allow to consider those things as not related to the trade sphere, but as objects that reflect some relations among the Türkic elite. However, the scarcity of available materials and mentioned hypothetical readings do not give grounds for specific conclusions ${ }^{7}$. To clarify possible interpretations, it is advisable to refer to additional information concerning the peculiarities in the distribution of Byzantine coins and their imitations in the territory of Inner Asia in the Early Middle Ages, as well as the role of the Sogdians in these processes.

As it was noted by the Chinese scholar Lin Ying (Lin Ying, 2003), Byzantine gold solids were placed in the burials of some members of the Chinese aristocracy, confidants and relatives of the imperial family, belonging to the period of the last quarter of the $6^{\text {th }}$ - beginning of the $2^{\text {nd }}$ decade of the $7^{\text {th }}$ centuries, i.e. from the Northern Qi Period to the Early Tang. The scholar points to a document \#1040 from the Ōtani Kōzui collection in the Ryukoku University Library, dating to the late $6^{\text {th }}$ or early $7^{\text {th }}$ centuries, where it is mentioned that such coins (Chinese jin-qian 金錢) in single exemplar were attached as gifts to letters sent by members of the Western Türkic ruling strata to the court of Gaochang. Then through Gaochang, these coins get into China. At that moment in the Celestial Empire it was not knew about the

\footnotetext{
Despite some attempts to read the signs on the product from the Uvgunt complex (Klyashtornyj, Savinov, Shkoda, 1990: 12-13; Seregin, Tishin, 2017: 257-259), the presence of runic inscriptions remains hypothetical. Now we can admit the possibility of comparing signs on both objects (Uvgunt, Tuekta) with graphemes of Pahlavi writing.
}

connection of the products with the Byzantine Empire, as a result of which they were associated with the Türks. The sources also contain information about giving some gold coins by Chinese emperors to their close followers, who exceled in military campaigns against the Türks, including those whose graves were mentioned above. Therefore, according to Lin Ying, the items analysed found in the burials of the aristocracy of the Celestial Empire had the function of a kind of insignia given for their services in life (Lin Ying, 2003).

As it was suggested by H. Wang about coin imitations from the Astana Tombs associated with Gaochang, those were products of local origin. They were used as an element of the accompanying burial inventory, but by no means as money (Wang, 2004: 29). Thus, according to the researcher, an one-sided imitation of a Byzantine solid of the $5^{\text {th }}-6^{\text {th }}$ centuries from the collection of the British Museum (Stein. IA.XII.b.1), which has a hole in its upper left part at about 10 o'clock point along the circumference, performed rather a decorative function (Wang, 2004: 29, fig. 7).

However, it is also known in China another group of burials with Byzantine coins. These are the graves located mainly in the Ningxia province and belonging to the period from the middle of the $6^{\text {th }}$ to the beginning of the $2^{\text {nd }}$ decade of the $8^{\text {th }}$ centuries and associated to the Sogdians. Numerous coin imitations and bracteates of Byzantine solids were found here (Lin Ying, 2005). This fact indirectly supports the mention that the production of these imitations is connected precisely with the Sogdians themselves. It is significant that in the $6^{\text {th }}-8^{\text {th }}$ centuries both in Sogd and among the representatives of the Sogdian colonies in China, golden Byzantine solids and their imitations were used not in the trade, but mainly in the religious sphere (Lin Ying, 2005). At the same time, it is known that Byzantine coins became the prototype for one of the early samples of coins of the Western Türkic Qaghanate, minted in the settled agricultural centres of Central Asia (Babayarov and Kubatin, 2013).

It seems most likely the Sogdian origin of the coin-shaped indication from the Tuekta 
complex, as well as other similar things, including copies of Byzantine coins from Early medieval Türks sites. At the same time, there was no money circulation among the Eastern Türks, and, and therefore no their own coinage. Judging by the available materials, rare Chinese coins found in the burials of nomads or discovered as chance finds in the territory that was part of the Eastern Türkic Qaghanate were used as amulets or jewellery for a costume (Tishkin and Seregin, 2013: 50-55). As an evidence of a change in the original functions of the things they can be seen the some cases of finds of benevolent inscriptions on them (Klyashtornyj, 2006: 117).

All the above information taken together allows us to make a hypothetical assumption about the functional purpose of a coin-shaped indication from the Tuekta complex, as well as similar finds from other archaeological sites of the Türks. It is possible that such products were close in function to what was paitsza (Chinese paizi 牌子) in the Tang Empire, then among Khitan, Jurchen, Tangut and Mongols. In these polities, it acted as a kind of certificate, given to the holder of a particular office or endowed with the some functions to carry out an assignment (Kychanov, 2008: 186-188; Pochekaev, 2009: 55-56; etc.).

It should be noted that it was already indirectly suggested earlier, basing on an attempt to read one of the runic inscriptions, the opinion that the documents of this kind were among the Türks (Nadelyaev, 1974: 115-118). The hypo- thetical nature of the point put forward in this article is largely obvious, because of basing the fragmentary materials analyzed; however, the available data provides sufficient grounds for further discussion of such interpretation.

\section{Conclusion}

The study of the coin-shaped indication from the Tuekta complex showed the absence of identical products in the well-known numismatic collections. At the same time, consideration of the details of the image on this thing made it possible to outline a wide range of analogies illustrating the complex processes of cultural contacts in vast territories of Eurasia over a long chronological period.

An analysis of the available materials suggests that the coin-shaped indication from the Tuekta complex, as well as other similar type finds from the archaeological sites of the Türks of Inner Asia, are a kind of "social markers" to demonstrate their owners belong to elite of the nomad society and, possibly, reflect the presence of their certain powers. The interpretation of such things, given their scarcity and not always obvious context of their discovery, seems debatable. A further increase in the fund of available materials, as well as the involvement of a wide range of experts in the discussion, will make it possible to correct the assumptions made, and will also contribute to a clearer understanding of the functional purpose of coin-shaped indications in the early medieval nomadic society.

\section{References}

Babayarov, G., Kubatin, A. (2013). Byzantine impact on the iconography of Western Turkic coinage. In Acta Orientalia Academiae Scientiarum Hungaricae, 66, 1.

Clauson, G. (1972). An Etymological Dictionary of Pre-Thirteenth-Century Turkish. Oxford: Clarendon Press, XLVIII, 989 p.

Gavrilova, A.A. (1965). Mogil'nik Kudyrge kak istochnik po istorii altaiskikh plemen [The Kudyrge Cemetery as a Source for the History of the Altai Tribes]. Moscow, Leningrad, Nauka, $146 \mathrm{p}$.

Gorbunov, V.V., Serov, V.V. (2015). Numizmaticheskii kompleks iz tiurkskogo kurgana Shoron Bumbagar [Numismatic Complex from Turkic Mound of Barrow Shoron Bumbagar]. In Izvestiia Altaiskogo gosudarstvennogo universiteta, Seriia Istoricheskie nauki i arkheologiia [In the Bulletin of Altai State University, Historical Sciences and Archaeology series], 1-4(88), 72-78.

Drevneishie gosudarstva Kavkaza i Srednei Azii (1985) [The Most Ancient States of the Caucasus and Central Asia]. Moscow, Nauka, $496 \mathrm{~s}$.

Drevnetiurkskii slovar' (1969). [A Dictionary of Old Turkic]. Leningrad, Nauka, XXXVIII, 714 p. 
Nikolay N. Seregin, Vladimir V. Tishin... "Forgotten" Coin-Shaped Indication from the Early Medieval Complex...

D’yakonova, N.V. (1995). Shikshin. Materialy Pervoi Russkoi Turkestanskoi ekspeditsii akademika S.F. Ol'denburga. 1909-1910 gg. [Shikshin. Materials of the First Russian Turkestan expedition of academician S.F. Oldenburg. 1909-1910]. Moscow, Vostochnaia literatura, 304 p.

D’yakonova, N.V., Sorokin, S.S. (1960). Khotanskie drevnosti [Khotan Antiquities]. Leningrad, Gosudarstvennyi Ermitazh, 128 p.

Evtiuhova, L.A., Kiselev, S.V. (1941). Otchet o rabotakh Saiano-Altaiskoi arkheologicheskoi ekspeditsii v 1935 g. [Report on the works of the Sayan-Altai archaeological expedition in 1935]. In Trudy Gosudarstvennogo istoricheskogo muzeia [In Writings of the State Historical Museum], 16, 75-117.

Kiselev, S.V. (1949). Drevniaia istoriia Iuzhnoi Sibiri [The Ancient History of Southern Siberia]. Moscow, Leningrad, Akademiia nauk SSSR, 364 p.

Kiselev, S.V. (1951). Drevniaia istoriia Iuzhnoi Sibiri [The Ancient History of Southern Siberia]. Moscow, Akademiia nauk SSSR, 638 p.

Klyashtornyj, S.G. (2006). Pamiatniki drevnetiurkskoi pis'mennosti i etnokul'turnaia istoriia Tsentral'noi Azii [Old Turkic Writing Monuments and Ethno-cultural History of Central Asia]. St-Petersburg, Nauka, $591 \mathrm{p}$.

Klyashtornyj, S.G., Savinov, D.G., Shkoda, V.G. (1990). Zolotoi brakteat iz Mongolii. Vizantiiskij motiv v central'noaziatskoi torevtike [Golden brakteate from Mongolia. The Byzantine motif in the Central Asian toreutics]. In Informatsionnyi biulleten' Mezhdunarodnoi assotsiatsii po izucheniiu kul'tur Tsentral'noi Azii [Newsletter of the International Association for the Study of Cultures of Central Asia], 16, 5-16.

Kononov, A.N. (1980). Grammatika iazyka tiurkskikh runicheskikh pamiatnikov VII-IXvv. [A Grammar of the Language of the Turkic Runic Monuments of the $7^{\text {th }}-9^{\text {th }}$ centuries]. Leningrad, Nauka, $170 \mathrm{p}$.

Kubarev, G.V., Kubarev, V.D. (2003). Pogrebenie znatnogo tiurka iz Balyk-Sooka (Tsentral'nyi Altai) [Noble Turk grave in Balyk-Sook (Central Altai).], In Arkheologiia, etnografiia i antropologiia Evrazii [Archeology, Ethnography and Anthropology of Eurasia], 4, 64-82.

Kychanov, E.I. (2008). Istoriia tangutskogo gosudarstva [A History of the Tangut State]. St. Petersburg, Fakul'tet filologii i iskusstv Sankt-Peterburgskogo universiteta, $774 \mathrm{p}$.

Lin Ying. (2003). Western Turks and Byzantine gold coins found in China. Electronic resource. Transoxiana, 6. Available at: www.transoxiana.org/0106/lin-ying turks solidus.html

Lin Ying. (2005). Sogdians and the Imitations of Byzantine Gold Coins Unearthed from the Heartland of China. In Ërān ud Anērān: Studies Presented to Boris Il'ič Maršak on the Occasion of his $70^{\text {th }}$ Birthday. Venezia.

Lin Ying (2005a). Solidi in China and monetary culture along the Silk Road. In The Silk Road, 3, 2 , $16-20$.

Mkrtychev, T.K. (2002). Buddiiskoe iskusstvo Srednei Azii (I-X vv.) [Buddhist Art of Central Asia $\left(1^{s t}-10^{\text {th }}\right.$ centuries $\left.)\right]$. Moscow, Akademkniga, $286 \mathrm{p}$.

Navan, D., Sum'yabaatar, B. (1987). The importance of the Mongolian language is very topical [Овог монгол хэл бичийн чухаг дурсгал]. Ulaanbaatar: Shinzhlekh Uhaany Akademijn hevlel, 155 p.

Nadelyaev, V.M. (1974). Drevnetiurkskaia veritel'naia gramota [Old Turkic credential]. In Izvestiia Sibirskogo otdeleniia Akademii nauk SSSR, Seriia obshchestvennykh nauk [Bulletin of the Siberian Branch of the USSR Academy of Sciences, Series of Social Sciences], 3, 11, 115-118.

Ochir, A., Erdenebold, L., Harzhaubaj, S., Zhantegin, H. (2013). Experimental excavation of ancient nomads: Bulann Aimag's Bayannuиr Soum's Red Square Survival Reports [Эртний нүҮдэлчдийн бунхант булины малтлага судалгаа: Булган Аймгийн Баяннуур Сумын Улаан хэрмийн Шороон бумбагарын малтлагын тайлан]. Ulaanbaatar: «Soyombo Printing» Hevlelijn Yjldver, 290 p.

Pochekaev, R.Yu. (2009). Pravo Zolotoi Ordy [Law System of the Golden Horde]. Kazan', Fen, 260 p.

Pugachenkova, G.A. (1971). Skul'ptura Halchaiana [Sculpture of Khalchayan]. Moscow, Iskusstvo, $202 \mathrm{p}$.

Pugachenkova, G.A. (1982). Iskusstvo Gandkhary [Art of Gandhara]. Moscow, Iskusstvo, 196 p.

Seregin, N.N., Tishin, V.V. (2017). Nekotorye aspekty interpretatsii monetnykh indikatsii (brakteatov) iz pogrebal'nykh kompleksov tiurok Tsentral'noi Azii [Some Aspects of Interpretation of the Coin Indica- 
tions from the Turkic Burial Complexes in Inner Asia]. In Izvestiia Altaiskogo gosudarstvennogo universiteta, Seriia Istoricheskie nauki i arkheologiia [Bulletin of Altai State University, Historical Sciences and Archeology Series], 2 (96), 255-262.

Smirnova, O.I. (1981). Svodnyi katalog sogdiiskikh monet. Bronza [General catalogue of Sogdian coins. Bronze]. Moscow, Nauka, $548 \mathrm{~s}$.

Sravnitel'no-istoricheskaia (2006). grammatika tiurkskih iazykov. Pratiurkskii iazyk-osnova. Kartina mira pratiurkskogo etnosa po dannym iazyka [Comparative-historical grammar of Turkic languages: the Proto-Turkic period. The Worldview of the Proto-Turkic Ethnic Group Based on the Linguistic Data]. Moscow, Nauka, 2006, 908 p.

Sear D.R. (1987). Byzantine Coins and Their Values. London, Seaby, 578 p.

Shmonievskii, B.Sh. (2016). Vizantiiskaia moneta i ee podrazhaniia (moneta mertvykh) na primere nakhodok iz pogrebenii Avarskogo kaganata, na Shelkovom puti i prilegaiushchikh territorii (VI-VIII vv.) [The Byzantine Coin and its Imitation (Coin of the Dead) on the Example of FInds from the Burials of the Avar Kaganate, on the Silk Road and adjacent Territories $\left(6^{\text {th }}-8^{\text {th }}\right.$ centuries)]. In Kratkie soobshcheniia Instituta arkheologii [Brief Communications of the Institute of Archeology], 244, 254-274.

The Silk Road: Trade, Travel, War and Faith: Exhibition Catalogue / Ed. by S. Whitfield with U. Sims-Williams. Chicago, Serindia, 2004. 366 p.

Tishkin, A.A., Seregin, N.N. (2013). Kitaiskie izdeliia iz arkheologicheskikh pamiatnikov rannesrednevekovykh tiurok Tsentral'noj Azii [Chinese Products from Archaeological Sites of the Early Medieval Turks of Central Asia]. In Teoriia i praktika arkheologicheskikh issledovanii [Theory and Practice of Archaeological Research], 1 (7), 49-72.

Vasil'ev, D.D. (1983). Graficheskii fond pamiatnikov tiurkskoj runicheskoi pis'mennosti Aziatskogo areala (opyt sistematizatsii) [Graphic Fund of Monuments of the Turkic Runic Writing of the Asian Area (An Experience of Systematization)]. Moscow, Nauka, $146 \mathrm{p}$.

Wang H. (2004). How Much for a Camel? A New Understanding of Money on the Silk Road before AD 800. In The Silk Road: Trade, Travel, War and Faith: Exhibition Catalogue / Ed. by S. Whitfield with U. Sims-Williams. Chicago, Serindia, 24-33. 


\title{
«Забытая» монетовидная индикация
}

\section{из раннесредневекового комплекса Туэкта (Центральный Алтай)}

\author{
H.Н. Серегин ${ }^{a}$, В.В.Тишин ${ }^{6}$, В.В. Серов ${ }^{\text {B }}$ \\ ${ }^{a}$ Алтайский государственный университет \\ Российская Федераичи, Барнаул \\ ${ }^{6}$ Институт монголоведения, буддологии \\ и тибетологии СО РАН \\ Российская Федерачия, Улан-Удэ \\ ${ }^{8}$ Алтайский институт экономики \\ Российская Федеращия, Барнаул
}

\begin{abstract}
Аннотация. Статья посвящена введению в научный оборот и комплексной характеристике уникальной находки - монетовидной индикации из раннесредневекового погребения памятника Туэкта в Центральном Алтае. Раскопки данного объекта осуществлены в 1930-е гг. Саяно-Алтайской экспедицией под руководством С. В. Киселева, однако до настоящего времени обозначенная находка не привлекала внимания исследователей. В статье представлено детальное описание монетовидной индикации, анализ нанесенных изображений, характеристика археологического контекста обнаружения предмета, возможности прочтения фиксирующихся знаков, а также опыт интерпретации изделия в конкретном историко-культурном контексте и с учетом материалов, полученных в последние десятилетия. Установлено отсутствие идентичных находок в известных нумизматических коллекциях. При этом рассмотрение деталей изображения на монетовидной индикации позволило обозначить широкий круг аналогий, демонстрирующих сложные процессы культурных контактов на обширных территориях Евразии в течение длительного хронологического периода. Авторы пришли к заключению, что анализируемое изделие, а также другие подобные находки из памятников тюрок Центральной Азии представляют собой своего рода «социальные маркеры», демонстрирующие принадлежность их владельцев к элитным слоям общества номадов и, возможно, отражают наличие у них определенных полномочий. Предложенная интерпретация таких предметов, учитывая их немногочисленность, а также не всегда очевидный контекст обнаружения, представляется дискуссионной и требует расширения источниковой базы в ходе дальнейших археологических исследований.
\end{abstract}

Ключевые слова: Алтай, раннее Средневековье, монетовидная индикация, Туэкта, тюрки, погребение, интерпретация, социальная история.

Научная специальность: 07.00.00 - исторические науки и археология. 